\title{
Restoration of a degraded oak forest in Mexico City by introducing tree native species
}

cceative commons

Botamical Sciences

95 (4): 595-609, 2017

DOI: 10.17129/botsci.903

Received:

September 28th, 2016

Accepted:

April 17th, 2017

Associated Editor:

Juan Núñez Farfán
Copyright: (C) 2017 Chávez-García $\&$ Mendoza. This is an open access article distributed under the terms of the Creative Commons Attribution License, which permits unrestricted use, distribution, and reproduction in any medium, provided the original author and source are credited.

Instituto de Ecología, Universidad Nacional Autónoma de México, México.

* Corresponding author: anamendoza@ecologia. unam.mx
Elizabeth Chávez-García and Ana Mendoza*

\section{Abstract}

Background: Uncontrollable urban expansion and population growth converted Mexico City into one of the largest cities of the world. Ravines remain important oak forest relicts that should be conserved and restored to recover the biodiversity and the ecological services they provide.

Question: Is an open area equally appropriate for ecological restoration as is the forest edge? Does plant performance of introduced species vary between the open area and the forest edge?

Study species: Prunus serotina, Quercus rugosa, and Crataegus mexicana.

Study site: Oak forest in Barranca de Tarango, Mexico City; July 2010 to July 2012.

Methods: Plants of these species were planted in the forest edge and in an open area adjacent to it, where soil properties and light conditions were measured.

Results: Soil properties and leaf area index were better and significantly larger, respectively, in the forest edge than in the open area. Stem height, basal area and number of sprouts of these plants did not differ between sites or years. Plants of C. mexicana produced the largest number of sprouts, followed by Q. rugosa. Survival of plants was similar in the open area and the forest edge; however, $P$. serotina had the lowest survival, and $C$. mexicana the highest.

Conclusions: $Q$. rugosa and $C$. mexicana with higher survival are more likely to perform better in both sites than P. serotina, on account of their ability to produce more sprouts. The forest edge is better than the open area for introducing native species in Barranca de Tarango. Low performance of these species was mainly due to the construction of a highway that crosses the study area.

Key words: forest edge, oak forest, ravine, restoration, sprouts.

\section{Restauración de un bosque de encino degradado en la Ciudad de México mediante introducción de especies arbóreas nativas}

\section{Resumen}

Antecedentes: La expansión urbana y el crecimiento poblacional convirtieron a la Ciudad de México en una de las más grandes del mundo. Las barrancas, como relictos importantes de bosques de encinos, deben ser conservadas y restauradas para recuperar la biodiversidad y los servicios ambientales que proporcionan.

Preguntas: ¿Una zona abierta es igualmente apropiada para la restauración ecológica como lo es el borde del bosque? ¿El desempeño de especies introducidas varía entre la zona abierta y el borde del bosque?

Especies de estudio: Prunus serotina, Quercus rugosa y Crataegus mexicana.

Sitio de estudio: Bosque de encino en la Barranca de Tarango, Ciudad de México; julio de 2010 a julio 2012.

Métodos: Estas especies se plantaron en el borde del bosque y en un área abierta adyacente a éste, donde se midieron propiedades del suelo y condiciones lumínicas.

Resultados: Las propiedades del suelo fueron mejores y el índice de área foliar significativamente mayor en el borde que en el área abierta. La altura, área basal del tallo y el número de rebrotes no difirieron entre sitios ni entre años. Plantas de $C$. mexicana produjeron la mayor cantidad de rebrotes, seguidas de $Q$. rugosa. La supervivencia fue similar en ambas zonas, pero $P$. serotina tuvo la menor supervivencia y $C$. mexicana la mayor.

Conclusiones: Q. rugosa y C.mexicana se desempeñan mejor que P. serotina en ambos sitios, debido a su habilidad para producir rebrotes. El borde de bosque presenta mejores condiciones para introducir especies nativas en la Barranca de Tarango. El pobre desempeño de estas especies se debió a la construcción de una carretera que cruza el área de estudio.

Palabras clave: barranca, bosque de encino, rebrotes, restauración, zona de borde. 


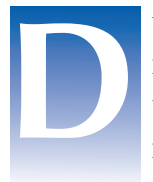

uring the second half of the last century urban and population growth of Mexico City converted it into one of the largest cities of the world. Between 1950 and 1980 mean annual growth rate was $4.8 \%$, mainly due to rural immigration (Ezcurra 1990). In only one decade (1970-1980) more than 3 million people from rural areas established in Mexico City (Calderón \& Hernández 1987). The expansion of the city continues nowadays by unregulated growth of new marginal settlements, thus decreasing agricultural and natural areas around it. This, in turn, reduces groundwater recharge and carbon dioxide capture while increasing air pollution and modifying climatic conditions (Maderey-Rascón \& Carrillo-Rivera 2005, Awal et al. 2010, Ayanlade 2016, Lu et al. 2016).

The persistent social pressure upon natural resources involves deforestation of large areas of land causing reductions and fragmentation of forest areas and increases in forest edges (Lovejoy et al. 1986, Nascimento et al. 2006, Laurance et al. 2011). Ravines in Mexico City, particularly those located in the southwestern part of the city, have escaped from the excessive growth of the urban area, due to its topographic characteristics and the difficulties for human settlements. These and the climatic conditions have contributed to maintain vegetation relicts of oak forests, which provide numerous ecological services. However, the lack of coordination and agreement between local authorities and the unplanned urban development have caused serious problems to the ravines. Among these are stream contamination, slope destabilization, imbalance of hydrological functions, loss of biodiversity, and a constant danger to the inhabitants that illegally have occupied the land (Canedo-Castro 2007, SMAGDF 2010).

One of the main goals in restoration programs is the conservation of vegetation by creating buffer zones that minimize temperature and moisture changes (Gascon \& Lovejoy 1998), increasing the size of the fragments and reducing the edge effects. Environmental conditions vary among the forest, the edges and the outside. While incidence of light, wind and temperature are larger in the forest edge than inside the forest, moisture content in the air and soil are smaller in the edge than in the forest (Williams-Linera et al. 2002). Microclimatic conditions outside the forest are even more severe than in the forest edge, resulting in higher temperature and lower relative humidity of the air, lower soil moisture retention and lower litter decomposition (Saunders et al. 1991, Matlack 1993, Alvarez-Aquino et al. 2004, Quintana-Ascencio et al. 2004). On the other side, tolerance of plants to different micro environmental conditions (sunlight, wind, high and low temperatures and low levels of moisture) might have significant effects on their establishment.

In the face of continued forest loss and degradation, we conducted an experiment aiming to restore a disturbed area of an oak forest in Mexico City, under the principle that ecological restoration is "an intentional activity that initiates or accelerates the recovery of an ecosystem with respect to its health, integrity and sustainability (SER 2002)". Ecological restoration aims to return the ecosystem that has been degraded, damaged, transformed or destroyed to its historic conditions (SER 2002). Hence, it is important to identify the reference ecosystem that will serve as the model to achieve such activity. Barranca de Tarango is an area originally covered by a temperate oak forest (reference ecosystem) and a xerophytic scrubland (sensu Rzedowski 1981), which has passed through several external pressures (García-Romero 2001, Canedo-Castro 2007), causing severe perturbations and needed to be restored. According to previous studies, the oak forest relicts were confined to the northern and southern parts of Barranca de Tarango, whereas induced grasslands, secondary vegetation and isolated trees were found between these forested areas (unpublished data). In order to contribute to connect these areas, improve the environmental conditions of Barranca de Tarango and preserve the original vegetation, we committed ourselves in assisting in the recovery of this forest by employing one of the most widely used ecological restoration practices consisting on planting tree native species (Harrington 1999, SER 2002) in a forest edge and an open area. It is known that forest edges are suitable places for the restoration of disturbed ecosystems (Bonfil \& Soberón 1999, Asbjornsen et al. 2004, López-Barrera \& Newton 2005, López-Barrera et al. 2006, Bueno \& Llambí 2015), but, is the open area equally appropriate for restoration as is the forest edge? To answer this question, we established experimental plots in a forest edge and an open area adjacent to it in order to introduce three native species. The aims of this study were: i) to characterize micro environmental conditions of the forest edge and open area by means of soil and light variables during the dry and rainy seasons, and ii) to estimate whether 
the performance (survival and growth) of these tree species differs between sites, on account of their differences in microclimatic conditions. Our hypothesis is that plants of Quercus rugosa Née (Fagaceae) will perform better in the forest edge than in the open area, since this is a shade tolerant species (Vázquez-Yanes et al. 1999). Contrary, plants of Crataegus mexicana Moc. Sessé (Rosaceae) and Prunus serotina subsp. capuli (Cav.) McVaugh (Rosaceae) will respond more favorably to the open area conditions because of their intolerance to shade conditions (Auclair 1975, Vázquez-Yanes et al. 1999). Results of this research will provide information on some actions to be taken for restoring urban forests of one of the world's largest cities that even now continues to be threatened by urban development.

\section{Material and methods}

Study site. The study was carried out in Barranca de Tarango (Figure 1), located in Delegación Álvaro Obregón, Mexico City $\left(19^{\circ} 14^{\prime} \mathrm{N}-19^{\circ} 25^{\prime} \mathrm{N}\right.$ and $\left.99^{\circ} 10^{\prime} \mathrm{W}-99^{\circ} 20^{\prime} \mathrm{W}\right)$, at an altitude between 2,330 and 2,580 m (GODF 2009, Guerra-Martínez 2012). It occupies an area of approximately 280 ha with a length of $6 \mathrm{~km}$. The oak forest in the area comprises two associations: Quercus castanea - Quercus obtusata with tree density of 448 individuals ha ${ }^{-1}$, and Quercus castanea - Quercus rugosa with tree density of 700 individuals ha ${ }^{-1}$ (Guerra-Martínez 2012).

Study species. The study species were Prunus serotina subsp. capuli, Quercus rugosa, and Crataegus mexicana; from now on the first species will be referred to as Prunus serotina. These tree species were chosen according to the following criteria: a) they are native of remnant oak forests of the city, b) they were found in previous studies carried out in the Barranca de Tarango (Guerra-Martínez 2012), and c) they are dispersed by small mammals and birds (VázquezYanes et al. 1999, GDF 2001, Rodríguez-Sánchez \& Cohen-Fernández 2003). Furthermore, these species are known for their tolerance to stressful conditions such as drought or pollution, and have been recommended for restoring degraded areas (Vázquez-Yanes et al. 1999, Martínez-González 2008).

Fieldwork. With the aid of satellite images and field surveys, in June 2010 we selected two experimental sites in Barranca de Tarango, one in the forest edge and the other in an open area.

Figure 1. Study site located in Barranca de Tarango, Delegación Álvaro Obregón, Mexico City, Mexico.

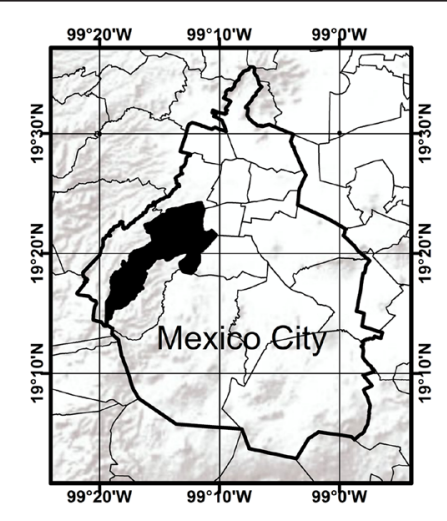

$115^{\circ} \mathrm{W} \quad 110^{\circ} \mathrm{W} \quad 105^{\circ} \mathrm{W} \quad 100^{\circ} \mathrm{W} \quad 95^{\circ} \mathrm{W} \quad 90^{\circ} \mathrm{W}$
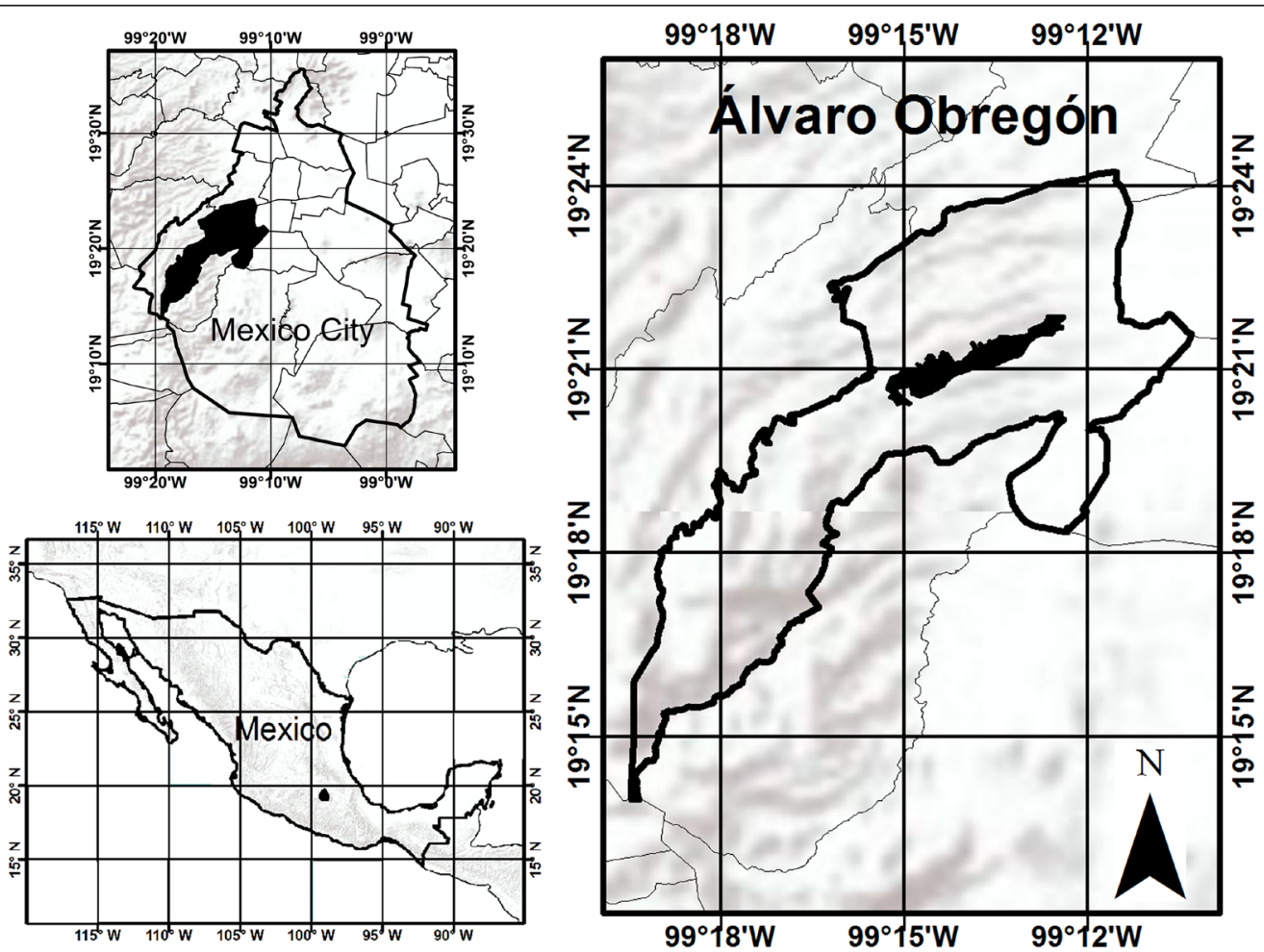
The forest edge was considered as the strip of land of approximately $50 \mathrm{~m}$, extending from the interior of the forest to the area totally devoid of vegetation, while the open area was that outside the forest at nearly 150-200 $\mathrm{m}$ far from the edge with few or no trees at all. In each site two plots were established. Each plot in the open area was of approximately $1,800 \mathrm{~m}^{2}$, located at 2,538 - 2,629 $\mathrm{m}$ asl, while plots in the forest edge were approximately $1,200 \mathrm{~m}^{2}$ each, located at 2,547- 2,553 $\mathrm{m}$ asl.

Site characterization. Environmental conditions such as air temperature and humidity, soil properties and solar radiation were used to characterize both sites. Air temperature and humidity were registered using sensors (HOBO Pro v2) placed in each plot. These variables were registered every two hours from August 2010 to July 2012. However, no data were collected in the open area during the last six months (February to July 2012) because sensors were stolen. Six sensors were placed randomly in the study area, three in the forest edge and three in the open area. The collected data were analyzed using monthly averages.

Soil properties in both sites were described by means of two soil profiles according to Siebe et al. (2006). Profiles were $40 \mathrm{~cm}$ in depth in the open area and $64 \mathrm{~cm}$ in the forest edge. Soils were classified according to the World Reference Base for Soil Resources (FAO-ISRIC-IUSS 2007). Parameters used to describe the soil in the field were texture, organic matter, bulk density, $\mathrm{pH}$, aggregate stability, aeration capacity, available water, and field capacity.

To describe the light environment of each site, we used hemispherical photographs, which have been used to estimate solar radiation penetration and canopy architecture (Chazdon \& Field 1987, Becker et al. 1989, Rich 1990, Chianucci \& Cutini 2012). Eleven photographs were taken in each area, always looking upward with the camera aligned to magnetic north and placed at a height between 57 and $67 \mathrm{~cm}$ from the soil surface. We used a Coolpix 990 digital camera (Nikon) set on stabilizing equipment designed by WinScanopy. Photographs were taken in each plot at a distance of $14 \mathrm{~m}$ between them during the dry (February 2011) and the rainy seasons (August 2011). Photographs were processed using Gap Light Analyzer (GLA) Version 2.0 (Frazer et al. 1999). The following parameters were considered for the analyses: i) canopy openness, percentage of open sky seen from beneath the forest canopy; ii) leaf area index, total leaf area per unit of land; iii) direct and diffuse radiation, amount of direct and diffuse sunlight, and iv) the total transmitted radiation, the sum of direct and diffuse radiations (Frazer et al. 1999, Régent Instruments 2002).

Plant performance (growth and survival). Plants used in this study were purchased in a nursery located in Mexico City. Plants of Quercus rugosa and Crataegus mexicana were 21 months old, whereas plants of Prunus serotina were 17 months old at the time of planting. We planted a total of 480 plants, 120 were planted in each of the two plots in the open area (240) and the same number in the two plots of the forest edge. The number of plants of each species varied according to the densities obtained by Guerra-Martínez (2012) in a previous study in Barranca de Tarango. The number of plants was 60 per plot of $Q$.rugosa and 30 plants per plot of each species of $C$. mexicana and P. serotina. Individuals of the three species were planted randomly in July 2010 at a distance of approximately $3 \mathrm{~m}$ between plants.

Before being planted, each plant was numbered and the height and diameter at the base of the stem were recorded. As some plants produced stems by clonal growth, the height of the main stem and the diameter of each individual stem also were recorded. Stems produced by clonal growth will be referred to as sprouts. Height was measured from the base of the stem to the apical bud. Stem diameter was measured at the base of it with a digital calliper. A permanent mark was placed at the base of the stem as a reference for measuring height and stem diameter during the following censuses (every 4 months). Growth of plants was assessed as the increase in height and basal area of the stem, as well as the number of sprouts. To estimate the basal area (BA) we used the following formula:

$$
B A=\pi(d / 2)^{2}
$$

where $\pi$ is the constant 3.1416 , and $d$ is the stem diameter.

From the date of planting, plants were registered monthly during two years. In order to estimate plant survival, in each census we recorded plant mortality and the possible causes of death. 
The following criteria were used to resolve whether a plant was dead: 1) the plant was not found in two consecutive records (disappearance), 2) the plant was uprooted, and 3) the plant was found completely dry, without foliage or sprouts (desiccation).

Data analysis. To prove whether monthly air temperature and relative humidity differed between sites (open area and forest edge), we used one-way ANOVA tests. Differences in canopy openness, leaf area index, direct, diffuse and total radiation between sites and seasons (dry and rainy) were analyzed by fitting generalized linear models (GLM) (McCullagh \& Nelder 1989). For the first variable (canopy openness), we used a binomial link distribution, whereas for the other four variables we used a Poisson link distribution. The null hypothesis considered that these variables did not differ between sites or seasons.

In order to test whether stem height and basal area of plants differed between sites each year, we used ANCOVA's tests. Stem height and basal area of plants of each species at the moment of planting (2010) were used as covariables to analyze height and basal area (response variables) in 2011. The same criterion was used one year later; height and basal area in 2012 were the response variables in the analyses, whereas stem height and basal area in 2011 were used as covariables. To compare plant size according to the number of sprouts of each species, in each site during 2011 and 2012, we used Kruskal-Wallis tests. Finally, differences in survival of plants of each species in each site were analyzed using a binomial logistic regression, with site as independent variable and death or survival of individuals as the binary response variable (Crawley 2005). The null hypothesis was that survivorship of plants is not affected by site. Analyses were carried out at a $95 \%$ level of significance, using STATISTICA (StatSoft, Inc. 2004), whereas light variables and survival analyses were performed with R (R Development Core Team 2014).

\section{Results}

Site characterization. The lowest average temperatures were registered in January 2012 in the open area $\left(8.6^{\circ} \mathrm{C}\right)$ and in December 2010 in the forest edge $\left(9.8^{\circ} \mathrm{C}\right)$. The highest average temperatures were recorded in May $2011 ; 20^{\circ} \mathrm{C}$ was registered in the open area and $18.6^{\circ} \mathrm{C}$ in the forest edge. However, temperature did not differ between sites $(F=0.059, p=0.8)$. The lowest average relative humidity was registered in March 2011, being higher in the forest edge (42.7\%) than in the open area (39\%); the highest average relative humidity was recorded in July 2011; $88.6 \%$ in the open area and $91.1 \%$ in the forest edge. However, no significant differences were found between sites $(F=0.23, p=0.64)$.

Soils were developed on pyroclastic materials in which the processes of formation have led to Regosols (open area) and Phaeozems (forest edge). Regosols are characterized by weakly developed soils in unconsolidated materials without diagnostic horizons and can have a low water

Table 1. Soil characteristics in the open area and in the forest edge in Barranca de Tarango, Mexico City.

\begin{tabular}{lcc} 
& Open area & Forest edge \\
\hline Soil type & Haplic Regosol (tephric) & Haplic Phaeozem (tephric) \\
Depth & $40 \mathrm{~cm}$ & $64 \mathrm{~cm}$ \\
Texture & Fine silt loam and clay loam & Silty clay loam \\
Organic matter & $1.8 \%$ & $4 \%$ \\
Bulk density & Medium $\left(1.4-1.5 \mathrm{~g} / \mathrm{cm}^{3}\right)$ & Low-medium $\left(1.0-1.38 \mathrm{~g} / \mathrm{cm}^{3}\right)$ \\
pH & $6.5-7$ & 6 \\
Rock fragments in the soil & Low $(<2 \%)$ & Low $(<2 \%)$ \\
Root density & Medium at top of soil & Medium at top of soil \\
Aggregate stability & $\left(6-10\right.$ fine roots per dm² $\left.\mathrm{dm}^{2}\right)$ & $(6-10$ fine roots per dm $)$ \\
Aeration capacity & Moderate & High \\
Available water & Low to medium $(4-7.5 \%)$ & Medium $(8 \%)$ \\
Field capacity & Low $\left(55.8 \mathrm{~L} / \mathrm{m}^{2}\right)$ & Medium $\left(125 \mathrm{~L} / \mathrm{m}^{2}\right)$ \\
\hline
\end{tabular}


Table 2. Light variables in the open area and the forest edge in Barranca de Tarango, Mexico City during the dry and rainy seasons. Values are means $\pm 1 \mathrm{SD}$.

\begin{tabular}{|c|c|c|c|c|}
\hline \multirow[t]{2}{*}{ Light variables } & \multicolumn{2}{|c|}{ Open area } & \multicolumn{2}{|c|}{ Forest edge } \\
\hline & Dry season & Rainy season & Dry season & Rainy season \\
\hline Canopy openness (\%) & $72.3 \pm 10.4$ & $66.3 \pm 6.6$ & $51.5 \pm 16.9$ & $48.4 \pm 12.5$ \\
\hline Leaf area index $\left(\mathrm{m}^{2} \mathrm{~m}^{-2}\right)$ & $0.2 \pm 0.2$ & $0.2 \pm 0.1$ & $0.6 \pm 0.4$ & $0.6 \pm 0.3$ \\
\hline Direct radiation $\left(\mathrm{mol} \mathrm{m}^{-2} \mathrm{~d}^{-1}\right)$ & $16.9 \pm 1.3$ & $20.3 \pm 1.2$ & $11.1 \pm 5.3$ & $15.2 \pm 3.4$ \\
\hline Diffuse radiation $\left(\mathrm{mol} \mathrm{m}^{-2} \mathbf{d}^{-1}\right)$ & $15.5 \pm 1.7$ & $18.2 \pm 1.0$ & $11.5 \pm 3.6$ & $13.0 \pm 2.8$ \\
\hline $\begin{array}{l}\text { Total transmitted radiation } \\
\left(\mathbf{m o l ~ m}^{-2} \mathbf{d}^{-1}\right)\end{array}$ & $32.4 \pm 2.9$ & $38.6 \pm 2.1$ & $22.6 \pm 8.8$ & $28.2 \pm 6.1$ \\
\hline
\end{tabular}

retention capacity. Phaeozems also developed in unconsolidated materials, including dark soils rich in organic matter (FAO-ISRIC-IUSS 2007, Table 1). Soil textures showed a homogeneous mixture of the three primary particles (clay, silt and sand). Stoniness was low (less than $2 \%$ ) and root density was medium in the first centimeters of the soil in both sites. Bulk density was slightly higher in the open area than in the forest edge. Soil depth, organic matter content, aggregate stability, aeration capacity, amount of available water and field capacity were higher in the forest edge than in the open area (Table 1).

Canopy openness, direct, diffuse and total radiation were higher in the open area than in the forest edge, whereas leaf area index was the other way around, lower in the open area than in the forest edge during the dry and rainy seasons (Table 2). Values of all light variables were smaller in the dry than in the rainy season, except canopy openness, whose value was larger in the dry than in the rainy season. Statistical analyses showed that all light variables differed significantly between sites, while direct, diffuse and total radiation also differed between seasons (Table 3).

Table 3. Generalized linear model (GLM) results of the light variables measured in the open area and the forest edge in Barranca de Tarango, Mexico City. Estimate values $\pm \mathrm{SE}$.

\begin{tabular}{lcccc}
\hline Parameter & Estimate & $\boldsymbol{t}$ value & $\boldsymbol{p}$ \\
\hline \multirow{3}{*}{ Canopy openness } & (Intercept) & $1.8536 \pm 0.3815$ & 4.859 & $<0.001$ \\
& site & $-0.7100 \pm 0.1710$ & -4.152 & $<0.001$ \\
& season & $-0.2468 \pm 0.1706$ & -1.446 & 0.1556 \\
\hline \multirow{3}{*}{ Leaf area index } & (Intercept) & $1.0918 \pm 0.6096$ & 1.791 & 0.0811 \\
& site & $1.4196 \pm 0.2821$ & 5.033 & $<0.001$ \\
& season & $0.1187 \pm 0.1898$ & 0.625 & 0.5353 \\
\hline \multirow{3}{*}{ Direct radiation } & (Intercept) & $7.5844 \pm 0.0605$ & 125.191 & $<0.001$ \\
& site & $-0.2934 \pm 0.0763$ & -3.846 & $<0.001$ \\
& season & $-0.1851 \pm 0.0758$ & -2.443 & 0.0190 \\
\hline \multirow{3}{*}{ Diffuse radiation } & (Intercept) & $7.5002 \pm 0.1300$ & 57.672 & $<0.001$ \\
& site & $-0.2711 \pm 0.0606$ & -4.474 & $<0.001$ \\
& season & $0.1193 \pm 0.0601$ & 1.983 & 0.0541 \\
\hline \multirow{2}{*}{ Total transmitted radiation } & (Intercept) & $8.2003 \pm 0.1401$ & 58.520 & $<0.001$ \\
& site & $-0.2922 \pm 0.0651$ & -4.483 & $<0.001$ \\
& season & $0.1634 \pm 0.0647$ & 2.525 & 0.0155 \\
\hline
\end{tabular}

Growth. Since the beginning of the experiment (2010), the largest plants in height and basal area were those of Crataegus mexicana, followed by Prunus serotina, and those of Quercus rugosa were the smallest (Figure 2a, b; Appendix 1). The first year (2011), in the open area the three species increased in the number of sprouts (Figure 2c; Appendix 1). Additionally, Q. rugosa and C. mexicana also increased in basal area. One year later (2012), Q. rugosa again increased in basal area and in the number of sprouts, whereas plants of P. serotina increased in height and basal area, and those of $C$. mexicana only increased in basal area.

In the forest edge Prunus serotina was the only species that increased in height in 2011; this species also increased in the number of sprouts as did Crataegus mexicana, and in Quercus ru- 
Figure 2. Growth in a) height, b) basal area, and c) number of sprouts of plants of P. serotina, $Q$. rugosa and $C$. mexicana planted in the open area and the forest edge in Barranca de Tarango, Mexico City, one (2011) and two (2012) years after being planted (2010). Error bars represent +1 standard deviation. a)

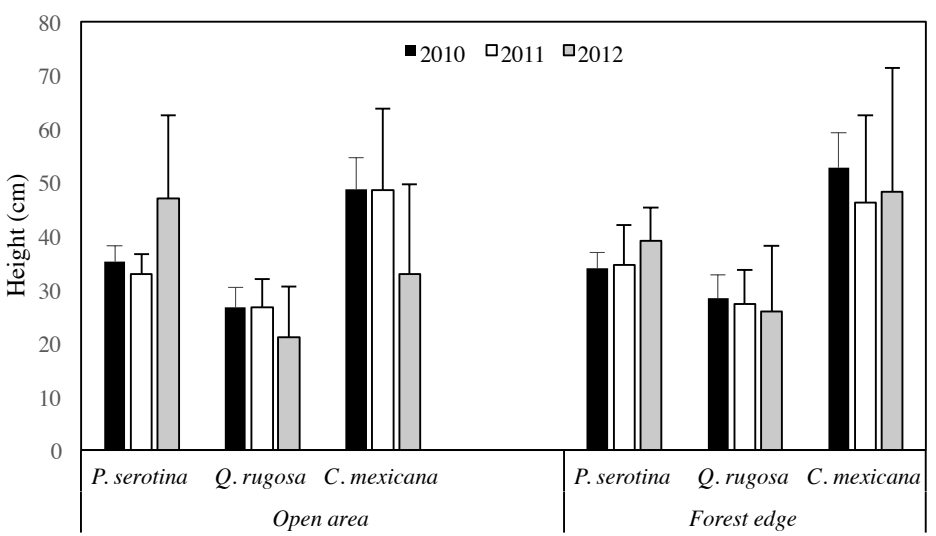

b)

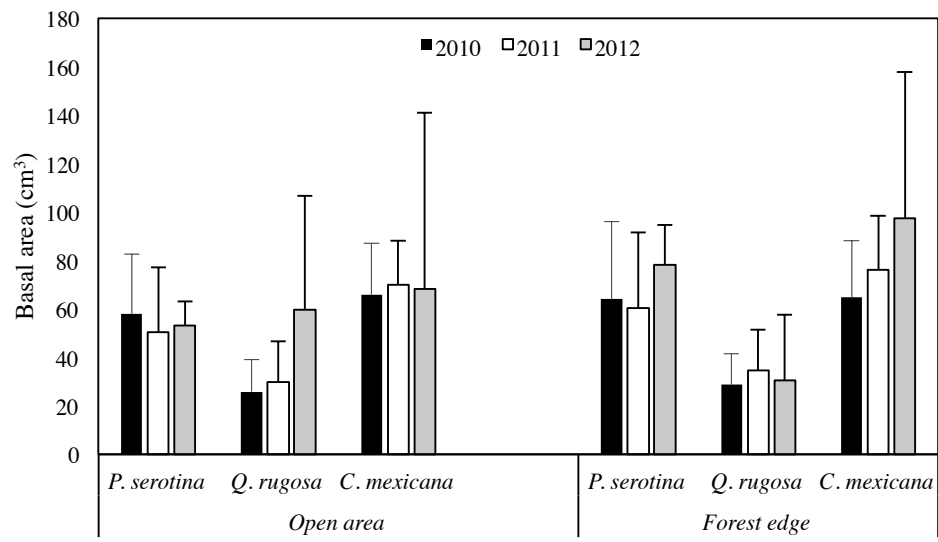

c)

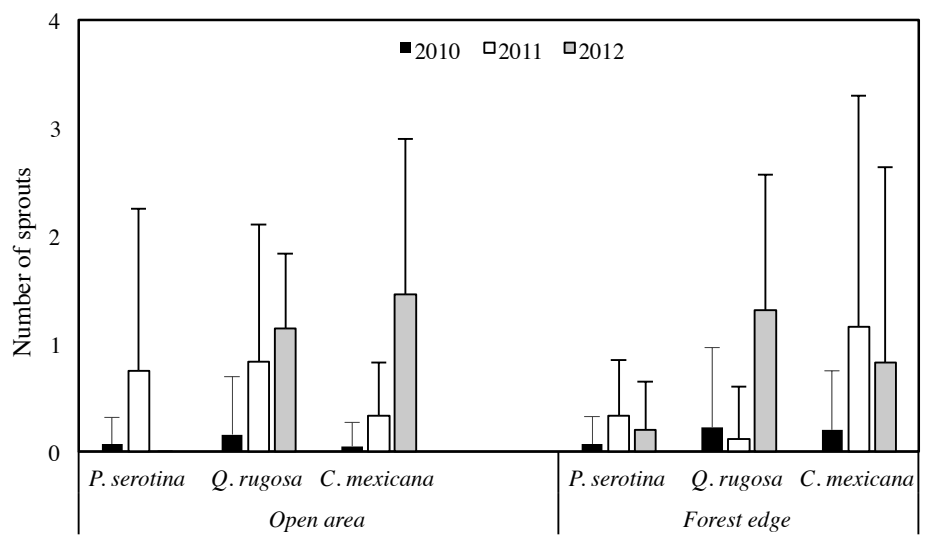

gosa the increment was in basal area (Figure 2 a, b, c; Appendix 1). In 2012, P. serotina and $C$. mexicana increased in height and basal area and $Q$. rugosa in number of sprouts. As plants of $P$. serotina experienced high mortality during the course of the experiment, no statistical analyses were carried out with this species due to the small sample size. However, results of the statistical analyses for the other two species did not show significant differences in height between the open area and the forest edge ( $Q$. rugosa $F=0.37, p=0.551 ; C$. mexicana $F=1.95, p=0.175)$, in basal area $(Q$. rugosa $F=2.45, p=0.133 ; C$. mexicana $F=1.83, p=0.187)$ and number of sprouts $(Q$. rugosa $F=0.39, p=0.75 ; C$. mexicana $F=100.45, p=0.07)$.

As no significant differences were found in height, basal area and number of sprouts between the open area and the forest edge, data from both sites were grouped together for each species in order to analyze whether these variables differed between years (Appendix 2). The only species 
Figure 3. Survival of plants of $P$. serotina, $Q$. rugosa and C. mexicana planted in: a) the open area, and $b$ ) the forest edge in Barranca de Tarango, Mexico City from July 2010 date of planting) to July 2012 (end of the study).

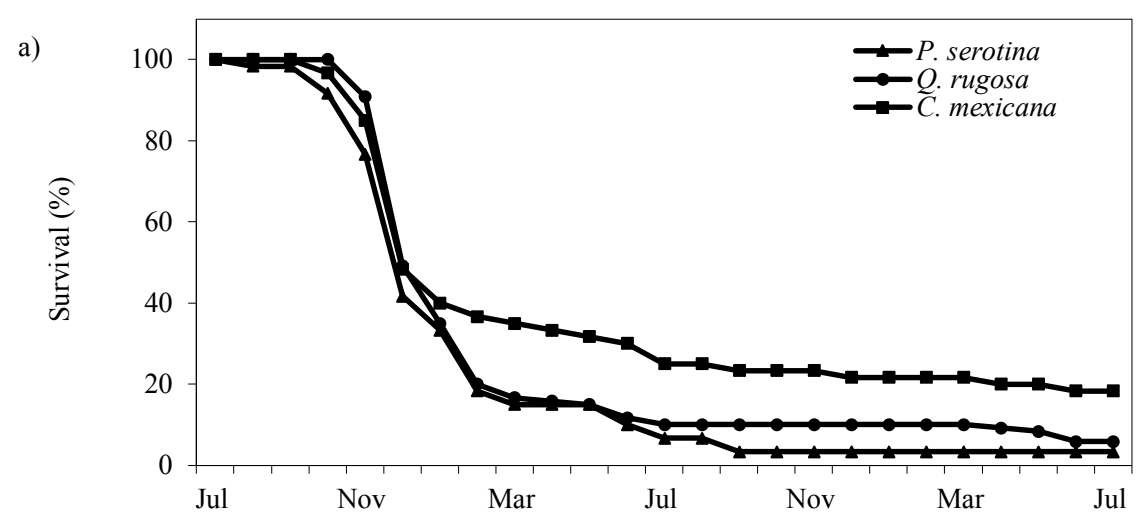

b)

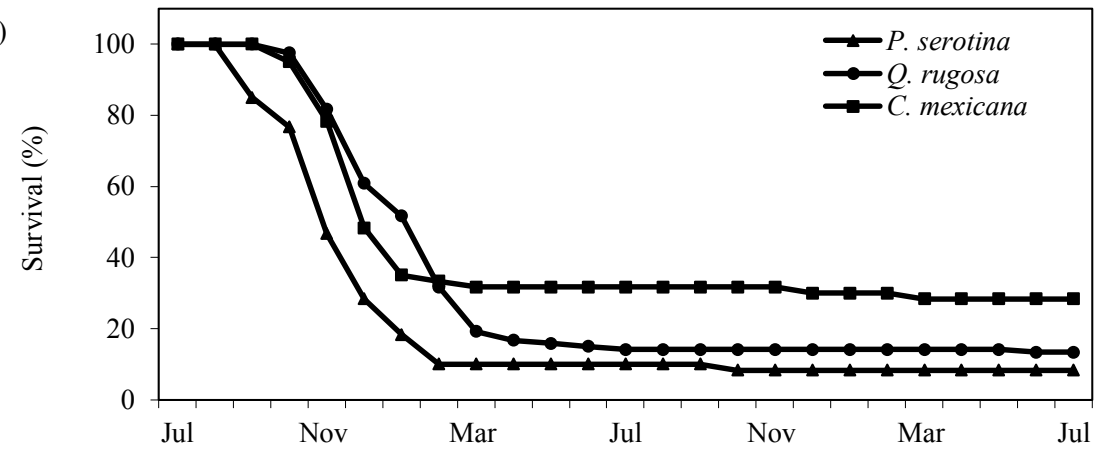

that increased in height was Prunus serotina and this only occurred in 2012; it also increased in basal area and number of sprouts in 2012 and in 2011, respectively. Quercus rugosa and Crataegus mexicana decreased in height in both years, but always increased in basal area and number of sprouts relative to the year before $(2010<2011<2012)$. However, no significant differences were found between years either in height $(Q$. rugosa $F=2.72, p=0.114 ; C$. mexicana $F=$ $2.10, p=0.158)$, basal area $(Q$. rugosa $F=2.53, p=0.126 ; C$. mexicana $F=0.42, p=0.518)$ or number of sprouts $\left(Q\right.$. rugosa $\chi^{2}=3.43, p=0.180 ; C$. mexicana $\left.\chi^{2}=3.71, p=0.156\right)$.

Survival. Plant survival of the three species was similar in both sites during the course of the study (Figure 3). During the first three months, plants in both sites showed high survival followed by an abrupt decrease. Mortality of plants of Prunus serotina occurred earlier in the forest edge. From January 2011, onwards, mortality of plants of the three species remained relatively constant both in the open area and the forest edge. No significant differences were found in plant survival of these species between sites (estimate $=0.727 \pm 0.516, t$ value $=1.410, p=0.189)$. At the end of the study (Figure 3), plants of Crataegus mexicana had the highest survival (18.3\% in the open area and $28.3 \%$ in the forest edge; $23.3 \%$ for both sites), and P. serotina had the lowest (3.3\% in the open area and $8.3 \%$ in the forest edge; $5.8 \%$ for both sites). Plants of Quercus rugosa had an intermediate survival in both sites $(5.8 \%$ in the open area and $13.3 \%$ in the forest edge; $9.5 \%$ for both sites). When the experiment finished, $8.3 \%$ of plants of the three species survived in the open area, while $15.8 \%$ survived in the forest edge.

\section{Discussion}

Since Quercus rugosa is a shade tolerant species and Crataegus mexicana and Prunus serotina are both intolerant to the same condition, we expected that $Q$. rugosa would have a better performance in the forest edge, while the other two would have it better in the open area. However, we did not observe a clear pattern of growth of each species in either site; rather, it seems that each had its own mechanism for growing. In the open area plants of the three species grew in the number of sprouts in 2011, Q. rugosa and C. mexicana also increased in basal area and 
none of the three species increased in height. In 2012, plants of Q. rugosa again increased in the number of sprouts and in basal area, P. serotina in height and basal area, but $C$. mexicana only in the number of sprouts. Contrary, in the forest edge plants of $Q$. rugosa increased in basal area in 2011 and in the number of sprouts in 2012. Nonetheless, in this site, plants of P. serotina increased in height in both years, in the number of sprouts in 2011 and in basal area in 2012, while those of $C$. mexicana increased in basal area in both years and additionally increased in the number of sprouts in 2011 and in height in 2012.

These results suggest that patterns of resource allocation of these species are not fixed; rather they can be modified to modulate growth, possibly due to the amount of resources stored before and after they were planted and/or the resources available in each site (i.e., light incidence or soil quality). It has been suggested that the amount of reserves in a developing seedling is crucial for enhancing the probability of establishment under hazardous environments (Westoby et al. 1996, Muller et al. 2000, Walters \& Reich 2000). Factors such as phenotypic plasticity induced by the environment (Whitman \& Agrawal 2009), or the developmental ontogeny of each species (Vesk 2006) might also explain the growing strategy followed by each species.

Evidently, height was not the best strategy for growing of plants of Quercus rugosa that never increased, but rather decreased or almost remained the same. Prunus serotina was the only species that always increased in height, except in the open area in 2011, but plants of Crataegus mexicana only increased in the forest edge in 2012. Decreases in height of the main stem of plants of the three species were mainly due to stem breakage. Therefore, height is not a reliable variable to measure growth of these species. Increases in basal area and number of sprouts were better strategies of growing for these species. It is likely that the increases observed in basal area were mainly due to the number of new sprouts, whereas decreases could be related to volume loss associated with water deficit (Cabrera-García et al. 1998). Seedlings of other oak species like $Q$.rugosa, $Q$. glaucoides M. Martens \& Galeotti and $Q$. candicans Née also experienced biomass losses when planted in the forest or in a degraded grassland (Cabrera-García et al. 1998, Bonfil \& Soberón 1999, Rubio-Licona 2009, Gómez-Cirilo 2010), due to either the death of the main stem that was broken before, or to the dry conditions in the sites where they were planted.

Our results show that clonal growth was the best strategy of growing for these species. It has been suggested that this is an important mechanism of plant regeneration and propagation that allows plant persistence in local and disturbance-prone environments (Espelta et al. 1999, Bond \& Midgley 2001, Chong et al. 2007). We found that plants of the three species in both sites had the ability to produce sprouts from basal meristems. However, it varied among species, and between years and sites, although the differences were not significant. Increases in the number of sprouts of Quercus rugosa and Crataegus mexicana occurred each year in the open area, whereas in the forest edge only happened in 2011 in C. mexicana and in 2012 in Q. rugosa. Similar results were reported by López-Barrera et al. (2006) who found that seedlings of several species of Quercus planted in open areas produced more sprouts than those along the forest edge. In the case of Prunus serotina, Auclair (1975) pointed out that clonal growth in plants of this species depends on forest structure.

It seems that the ability to produce sprouts is an important strategy for the survival of plants of these species, because if the main stem dies, the plant can produce new shoots, thus buffering severe disturbances. Our results suggest that clonal growth of these species is not a mechanism to propagate as in other species, but rather is a mechanism of growing at early stages (Mendoza \& Franco 1998). In addition, this mechanism reduced mortality risks of the whole plant, enhancing their survival in the open area and forest edge. Therefore, clonal growth is likely to confer advantages (Puijalon \& Bornette 2006) to plants of these species that were exposed to damage (see below).

Producing sprouts is not only a mechanism to grow at an individual level, but it is also valuable at the population level. Minnich et al. (1994) and Alfonso-Corrado et al. (2007) suggested that populations of Quercus eduardii Trel. and Q. potosina Trel. have survived after severe logging due to their ability to produce sprouts. Additionally, a demographic study carried out by Alfonso-Corrado et al. (2007) showed that clonal growth was more important to the population growth rate than seed production, suggesting that the former is crucial for the regeneration of 
these species in Sierra Fría, Aguascalientes, Mexico. Thus, for restoration purposes it is convenient to use species that produce sprouts to rehabilitate degraded areas.

It is likely that plants faced some transplanting stress while undergoing a period of adjustment to the new environment (Rietveld 1989). Of the three species, Prunus serotina was more affected than the other two species, although it was pointed out as a species tolerant to drought, or shallow and stony soils (Vázquez-Yanes et al. 1999), and common in degraded oak forests (García-Romero 2001). Plants of this species showed signs of stress (more leaf losses and changes in foliage color) to the conditions of the experimental sites since the very beginning. This effect also has been observed in species like Quercus pyrenaica Willd. and Pinus halepensis Mill. (Castro et al. 2006, Ariza-Mateos et al. 2008). The difficulty of plants of P. serotina to cope with the environment is clearly shown in the survival curves of this species in both sites. Even if the three species showed similar survival curves, plants of P. serotina experienced higher mortality, especially in the forest edge, where they started to die soon after being planted. We have no explanation whatsoever of its low performance in the study area, particularly in the forest edge, but it is likely that its intolerance to shadow or the effect of some herbivore or pathogen (Auclair 1975, Vázquez-Yanes et al. 1999, Hartman \& McCarthy 2004) might have contributed to this result.

Plants survived better in the forest edge than in the open area, although there were no statistical differences between the experimental sites. At the end of the study, plants of Crataegus mexicana had the highest survival in both sites and Quercus rugosa an intermediate. The study sites were rather homogenous in terms of temperature and relative humidity; however, soil and light characteristics were more favorable in the forest edge than the open area (Tables 1,2). These differences might explain the better performance of plants in the forest edge.

Survival of plants of the three species contrasts with the results of Hernández-García (2011) and Corona-Álvarez (2011), who found that survival of plants of Quercus rugosa (12 and 36 months old), was above $90 \%$, and that of plants of Quercus mexicana Bonpl. and Q. rugosa (36 months old) was above $80 \%$, respectively. Plants of these species also were planted in Barranca de Tarango, Mexico City (the same study site). However, twelve months old seedlings of Quercus rugosa planted in a degraded forest in Mexico City experienced high mortality (90\%) one year after planted (Cabrera-García et al. 1998) similar to what we found in this study. Our results also contrast with those reported by Löf et al. (2004), Schreeg et al. (2005) and Skousen et al. (2009) who found that survival of plants of Prunus serotina and P. avium (L.) L. was high (>80\%), one and three years after being planted, and between 50 and $80 \%$ during the second year in a reclaimed surface mine (Skousen et al. 2009). Similarly, in northwest Florida, 24 months old plants of $\mathrm{Cra}$ taegus marshallii Eggl. survived very well (>90\%) either in shade or full sun, with supplemental irrigation during the summer months (Fletcher et al. 2012) and those of C. monogyna Jacq. had more than $80 \%$ survival three years after planted in a farmland in Denmark (Löf et al. 2004).

The micro environmental conditions each plant encountered in its new habitat and the amount of stored resources influenced survival and growth of these species, as is shown by the survival curves and the large standard deviations observed for each growth variable, particularly during 2012. This suggests that each plant will allocate more resources to growing if microsite conditions where they were planted are appropriate (light, soil, humidity), whereas those planted in sites with poor conditions will invest more resources in establishing and surviving. It is also important to consider the quality of plants to be introduced. Ramírez-Contreras \& Rodríguez-Trejo (2009) pointed out that survival of established seedlings of Quercus rugosa was more than $37 \%$ when plants were taller and with larger stem diameters on account of their ability to compete with herbaceous plants. Monitoring the experimental plants is critical to determining whether these will follow certain patterns of growth over time. Nonetheless, a two-year period recording plant performance might not be enough to conclude about such patterns.

We presume that one of the main reasons for the low performance of these species is that while we started this experiment, the mayor of Mexico City authorized the construction of an expressway that crosses Barranca de Tarango, classified as "valued environmental area" (GODF 2009), meaning that it should be protected for the conservation of the biodiversity of the area (GODF 2010). Although authorities and builders assured that our experiment was going to be monitored and untouched, this did not occur. Lorries, machinery and workers moving through- 
out the area provoked side effects upon our experiment. We do not doubt that under other circumstances plants would have performed better as was shown by Hernández-García (2011) and Corona-Álvarez (2011) in Barranca de Tarango and by Löf et al. (2004), Schreeg et al. (2005), Skousen et al. (2009) and Fletcher et al. (2012) in other places.

Quercus rugosa, a shade tolerant species and Crataegus mexicana, an intolerant one, responded similarly in both sites. These species had the highest survival, probably because of their ability to produce more sprouts, strategy that allows these plants to reduce mortality risks. Therefore, both species are recommended to be planted in either site in Barranca de Tarango. Nevertheless, the forest edge seems to be better than the open area for introducing native species, mainly because of the better environmental conditions, but also for its greater distance to the construction of the highway. This study gives cues on certain mechanisms followed by these species after being planted. Also, it makes an important contribution to improve the selection of species to be introduced, as well as the area where they have to be planted in order to increase the probability of survival and the likelihood to persist in a new habitat.

\section{Acknowledgements}

We thank two anonymous reviewers for their helpful comments that greatly improved the quality of the manuscript. This research was supported by a scholarship from the National Council of Science and Technology (CONACyT) to E. Chávez-García, and by the Instituto de Ecología, Universidad Nacional Autónoma de México (UNAM). We thank the Posgrado en Ciencias Biológicas (UNAM) for their useful support, Irene Pisanty and Julieta Benítez for their helpful comments during the course of the study, María Esther Sánchez Coronado and Juan Pablo Castillo for their assistance in the statistical analyses, Rubén Pérez Ishiwara for his assistance with the analyses of the hemispherical photographs and Francisco Guerra for the preparation of Figure 1 of this manuscript. We also thank Alejandro González Ponce and Daniel Valle Vidal for their computing support and Graciela García Guzmán for her logistic support.

\section{Literature cited}

Alfonso-Corrado C, Clark-Tapia R, Mendoza A. 2007. Demography and management of two clonal oaks: Quercus eduardii and Q.potosina (Fagaceae) in Central Mexico. Forest Ecology and Management 251: 129-142. DOI: 10.1016/j.foreco.2006.11.004.

Alvarez-Aquino C, Williams-Linera G, Newton AC. 2004. Experimental native tree seedling establishment for the restoration of a Mexican cloud forest. Restoration Ecology 12: 412-418. DOI: 10.1111/ j.1061-2971.2004.00398.x.

Ariza-Mateos D, Navarro-Cerrillo RM, del Campo-García AD, Ibáñez-Lloris AJ, Jorrín-Novo JV. 2008. Influencia de la fecha de plantación al establecimiento de Pinus halepensis Mill. Aplicación de la proteómica a estudios de ecofisiología en campo. Cuadernos de la Sociedad Española de Ciencias Forestales 28: 111-117.

Asbjornsen H, Vogt KA, Ashton MS. 2004. Synergistic responses of oak, pine and shrub seedlings to edge environments and drought in a fragmented tropical highland oak forest, Oaxaca, Mexico. Forest Ecology and Management 192: 313-334. DOI: 10.1016/j.foreco.2004.01.035.

Auclair AN. 1975. Sprouting response in Prunus serotina Erhr.: Multivariate Analysis of site, forest structure and growth rate relationships. American Midland Naturalist 94: 72-87. DOI: 10.2307/2424539.

Awal MA, Ohta T, Matsumoto K, Toba T, Daikoku K, Hattori S, Hiyama T, Park H. 2010. Comparing the carbon sequestration capacity of temperate deciduous forests between urban and rural landscapes in central Japan. Urban Forestry \& Urban Greening 9: 261-270. DOI: 10.1016/j.ufug.2010.01.007.

Ayanlade A. 2016. Seasonality in the daytime and night-time intensity of land surface temperature in a tropical city area. Science of the Total Environment 557-558: 415-424. DOI: 10.1016/ j.scitotenv.2016.03.027.

Becker P, Erhart DW, Smith, AP. 1989. Analysis of Forest Light Environments Part I: Computerized Estimation of Solar-radiation from Hemispherical Canopy Photographs. Agricultural and Forest Meteorology 44: 217-232. DOI: 10.1016/0168-1923(89)90018-X.

Bond WJ, Midgley JJ. 2001. Ecology of Sprouting in Woody Plants: The Persistence Niche. Trends in Ecology and Evolution 16: 45-51. DOI: 10.1016/S0169-5347(00)02033-4.

Bonfil C, Soberón J. 1999. Quercus rugosa Seedling Dynamics in Relation to its Re-introduction in a Disturbed Mexican Landscape. Journal of Applied Vegetation Science 2: 189-200. DOI: 10.2307/1478982. 
Bueno A, Llambí LD. 2015. Facilitation and edge effects influence vegetation regeneration in old-fields at the tropical Andean forest-line. Applied Vegetation Science 18: 613-623. DOI: 10.1111/avsc.12186.

Cabrera-García L, Mendoza-Herrera PE, Peña-Flores V, Bonfil C, Soberón J. 1998. Evaluación de una plantación de encinos (Quercus rugosa Née) en el Ajusco Medio, Distrito Federal. Agrociencias 32: 149-156.

Calderón E, Hernández B. 1987. Crecimiento actual de la población de México. Ciencia y Desarrollo 76: 49-66.

Canedo-Castro M. 2007. Conservación y recuperación de barrancas del poniente de la Ciudad de México. In: Memoria del taller"Barrancas urbanas: soluciones a la problemática ambiental y opciones de financiamiento". Instituto Nacional de Ecología. México. <http://www.ine.gob.mx/descargas/dgipea/ pon_barranca_poniente cd_mex.pdf> (accessed October 19, 2013).

Castro J, Zamora R, Hódar, JA. 2006. Restoring Quercus pyrenaica forests using pioneer shrubs as nurse plants. Applied Vegetation Science 9: 137-142. DOI: 10.1111/j.1654-109X.2006.tb00663.x.

Chazdon RL, Field CB. 1987. Photographic estimation of photosynthetically active radiation: evaluation of a computerized technique. Oecologia 73: 525-532. DOI: 10.1007/BF00379411.

Chianucci F, Cutini A. 2012. Digital hemispherical photography for estimating forest canopy properties: current controversies and opportunities. iForest 5: 290-295. DOI: 10.3832/ifor0775-005.

Chong C, Edwards W, Waycott M. 2007. Differences in resprouting ability are not related to seed size or seedling growth in four riparian woody species. Journal of Ecology 95: 840-850. DOI: 10.1111/j.13652745.2007.01241.x.

Corona-Álvarez G. 2011. Reintroducción de Quercus mexicana Bonpl. y Quercus rugosa Neé en la Barranca de Tarango, México, D.F. MSc Thesis, Universidad Nacional Autónoma de México.

Crawley MJ. 2005. Statistics: An introduction using R. John Wiley \& Sons, Ltd., Chichester, England, UK. DOI: $10.1002 / 9781119941750$

Espelta JM, Sabaté S, Retana J. 1999. Resprouting dynamics. In: Rodà F, Retana J, Gracia CA, Bellot J. eds. Ecology of Mediterranean evergreen oak forest. Ecological Studies 137: 61-73. DOI: 10.1007/9783-642-58618-7.

Ezcurra E. 1990. De las chinampas a la megalópolis. El medio ambiente en la Cuenca de México. Serie "La Ciencia desde México". Fondo de Cultura Económica. México, D.F.

FAO-ISRIC-IUSS. Grupo de Trabajo WRB. 2007. Base referencial mundial del recurso suelo. Primera actualización 2007. Informes sobre Recursos Mundiales de Suelos No. 103. FAO, Roma. < http://www. fao.org/3/a-a0510s.pdf> (accessed December 10, 2010).

Fletcher EH, Thetford M, Sharma J, Jose S. 2012. Effect of root competition and shade on survival and growth of nine woody plant taxa within a pecan [Carya illinoinensis (Wangenh.) C. Koch] alley cropping system. Agroforest System 86: 49-60. DOI: 10.1007/s10457-012-9507-7.

Frazer GW, Canham CD, Lertzman KP. 1999. Gap light analyzer (GLA), Version 2.0. Imaging software to extract canopy structure and gap light transmission indices from true-colour fisheye photographs. User's manual and program documentation. Simon Fraser University, Burnaby, British Columbia, and the Institute of Ecosystem Studies, Millbrook, New York. <http://rem-main.rem.sfu.ca/forestry/downloads/Files/GLAV2UsersManual.pdf> (accessed February 10, 2012).

García-Romero A. 2001. Evolution of disturbed oak woodlands: the case of Mexico City's western forest reserve. The Geographical Journal 167: 72-82. DOI: 10.1111/1475-4959.00006.

Gascon C, Laurance WF, Lovejoy TE. 2003. Forest Fragmentation and Biodiversity in Central Amazonia. In: Bradshaw GA, Marquet PA. eds. How Landscapes Change. Ecological Studies (Analysis and Synthesis), vol 162. Berlin, Heidelberg: Springer. DOI: 10.1007/978-3-662-05238-9_4

GODF (Gaceta Oficial del Distrito Federal). 2009. Decreto por el que se Declara "Área de Valor Ambiental del Distrito Federal", con la Categoría de Barranca a la "Barranca de Tarango". Décima Séptima Época 637: 4-33. <http://centro.paot.org.mx/index.php/marconormativo/programasdf> (accessed October 20,2010).

GODF (Gaceta Oficial del Distrito Federal). 2010. Decreto por el que se establece como área natural protegida, con la categoría de zona de conservación la zona conocida con el nombre de "La Loma". Décima Séptima Época 822: 3-27. http://data.consejeria.cdmx.gob.mx/portal_old/uploads/gacetas/ 4bcd087fd6adc.pdf> (accessed August 11, 2011).

GDF (Gobierno del Distrito Federal). 2001. Manual técnico para establecimiento y manejo integral de las áreas verdes urbanas del Distrito Federal. Tomo II. México D.F. Secretaría del Medio Ambiente. Gobierno del Distrito Federal. México.

Gómez-Cirilo GY. 2010. Establecimiento de plántulas de Quercus glaucoides en un pastizal degradado. Bachelor's Thesis, Universidad Nacional Autónoma de México.

Guerra-Martínez FJ. 2012. Caracterización ecológica del bosque de encino de la Barranca de Tarango, México, D.F.: propuesta con miras a su restauración ecológica. MSc Thesis, Universidad Nacional Autónoma de México. 
Harrington, CA. 1999. Forests planted for ecosystem restoration or conservation. New Forests 17: 175190. DOI: $10.1023 / \mathrm{A}: 1006539910527$.

Hartman KM, McCarthy BC. 2004. Restoration of a Forest Understory After the Removal of an Invasive Shrub, Amur Honeysuckle (Lonicera maackii). Restoration Ecology 12: 154-165. DOI: 10.1111/j.10612971.2004.00368.x.

Hernández-García CI. 2011. Restauración ecológica de la Barranca Tarango, mediante la reintroducción de la especie Quercus rugosa Neé. MSc Thesis, Universidad Nacional Autónoma de México.

Laurance WF, Camargo JLC, Luizão RCC, Laurance SG, Pimm SL, Bruna EM, Stouffer PC, Williamson GB, Benítez-Malvido J, Vasconcelos HL, Van Houtan KS, Zartman CE, Boyle SA, Didham RK, Andrade A, Lovejoy TE. 2011. The fate of Amazonian Forest fragments: a 32-year investigation. Biological Conservation 144: 56-67. DOI:10.1016/j.biocon.2010.09.021.

Löf M, Thomsen A, Madsen P. 2004. Sowing and transplanting of broadleaves (Fagus sylvatica L., Quercus robur L., Prunus avium L. and Crataegus monogyna Jacq.) for afforestation of farmland. Forest Ecology and Management 188: 113-123. DOI: 10.1016/j.foreco.2003.07.013.

López-Barrera F, Newton A. 2005. Edge type effect on germination of oak tree species in the Highlands of Chiapas, Mexico. Forest Ecology and Management 217: 67-79. DOI: 10.1016/j.foreco.2005.05.048.

López-Barrera F, Manson RH, González-Espinosa M, Newton AC. 2006. Effects of the type of montane forest edge on oak seedling establishment along forest-edge-exterior gradients. Forest Ecology and Management 225: 234-244. DOI: 10.1016/j.foreco.2005.12.055.

Lovejoy TE, Bierregaard RO, Rylands AB, Malcolm JR, Quintela CE, Harper LH, Brown KS, Powell AH, Powell GVN, Schubart HOR, Hays MB. 1986. Edge and other effects of isolation on Amazon forest fragments. In: Soulé ME ed. Conservation biology: The science of scarcity and diversity. Massachusetts: Sinauer Associates Sunderland., 257-325.

Lu X, Yao T, Fung JCH, Lin C. 2016. Estimation of health and economic costs of air pollution over the Pearl River Delta region in China. Science of The Total Environment 566-567: 134-143. DOI: 10.1016/ j.scitotenv.2016.05.060.

Maderey-Rascón LE, Carrillo-Rivera JJ. 2005. El recurso agua en México: un análisis geográfico. Instituto de Geografía, UNAM. México, D.F.

Martínez-Gónzález L. 2008. Árboles y áreas verdes urbanas de la Ciudad de México y su zona metropolitana. México, D.F.: CONABIO - Fundación Xochitla, A.C.

Matlack GR. 1993. Microenvironment variation within and among forest edge sites in the Eastern United States. Biological Conservation 66: 185-194. DOI: 10.1016/0006-3207(93)90004-K.

McCullagh P, Nelder JA. 1989. Generalized Linear Models. Chapman and Hall/CRC. London-New York.

Mendoza A, Franco M. 1998. Sexual reproduction and clonal growth in Reinhardtia gracilis (Palmae), an understory tropical palm. American Journal of Botany 85: 521-521. DOI: 10.2307/2446436.

Minnich R, Sosa-Ramıírez J, Franco-Vizcaíno E, Barry WJ, Siqueiros-Delgado ME. 1994. Reconocimiento preliminar de la vegetación y de los impactos de actividades humanas en la Sierra Fría, Aguascalientes, México. Investigación y Ciencia 4: 23-29.

Muller I, Schmid B, Weiner J. 2000. The effect of nutrient availability on biomass allocation patterns in 27 species of herbaceous plants. Perspectives in Plant Ecology, Evolution and Systematics 3: 115-127. DOI: $10.1078 / 1433-8319-00007$.

Nascimento HEM, Andrade ACS, Camargo JLC, Laurance WF, Laurance SG, Ribeiro JEL. 2006. Effects of the surrounding matrix on tree recruitment in Amazonian forest fragments. Conservation Biology 20: 853-860. DOI: 10.1111/j.1523-1739.2006.00344.x.

Puijalon S, Bornette G. 2006. Phenotypic plasticity and mechanical stress: biomass partitioning and clonal growth of an aquatic plant species. American Journal of Botany 93: 1090-1099. DOI: 10.3732/ ajb.93.8.1090.

Quintana-Ascencio PF, Ramírez-Marcial N, González-Espinosa M, Martínez-Icó M. 2004. Sapling survival and growth of coniferous and broad-leaved trees in successional habitats in the highlands of Chiapas, Mexico. Applied Vegetation Science 7: 81-88. DOI: 10.1111/j.1654-109X.2004.tb00598.x.

R Development Core Team. 2014. R: A language and environment for statistical computing. R Foundation for Statistical Computing. Vienna, Austria. <http://www.R-project.org> (accessed September 23, 2016).

Ramírez-Contreras A, Rodríguez-Trejo DA. 2009. Efecto de calidad de planta, exposición y micrositio en una plantación de Quercus rugosa. Revista Chapingo. Serie Ciencias Forestales y del Ambiente 10: 5-11.

Régent Instruments. 2002. WinScanopy for canopy analysis. Régent Instruments Inc. Canada.

Rich PM. 1990. Characterizing plant canopies with hemispherical photographs. In Goel NS, Norman JM eds. Instrumentation for Studying Vegetation Canopies for Remote Sensing in Optical and Thermal Infrared Regions. Remote Sensing Reviews 5: 13-29. DOI: 10.1080/02757259009532119.

Rietveld WJ. 1989. Transplanting stress in bareroot conifer seedlings: its development and progression to establishment. Northern Journal of Applied Forestry 6: 99-107. 
Rodríguez-Sánchez LM, Cohen-Fernández EJ.eds. 2003. Guía de árboles y arbustos de la zona metropolitana de la Ciudad de México. México, D.F.: UAM-GDF.

Rubio-Licona LE. 2009. Reintroducción experimental de Quercus candicans Née (Fagaceae) en Chapa de Mota, Estado de México. MSc Thesis, Universidad Nacional Autónoma de México. México.

Rzedowski J. 1981. La Vegetación de México. Ciudad de México: Limusa.

Saunders DA, Hobbs RJ, Margules CR. 1991. Biological consequences of ecosystem fragmentation: a review. Conservation Biology 5: 18-32. DOI: 10.1111/j.1523-1739.1991.tb00384.x.

Schreeg LA, Kobe RK, Walters MB. 2005. Tree seedling growth, survival, and morphology in response to landscape-level variation in soil resource availability in northern Michigan. Canadian Journal of Forest Research 35: 263-273. DOI: 10.1139/X04-168.

SER (Society for Ecological Restoration Science \& Policy Working Group). 2002. The SER Primer on Ecological Restoration. <www.ser.org/> (accessed January 13, 2017).

Siebe C, Jahn R, Stahr K. 2006. Manual para la descripción y evaluación ecológica de suelos en el campo. Publicación Especial N 4. Chapingo, Edo. de México.

Skousen J, Gorman J, Pena-Yewtukhiw E, King J, Stewart J, Emerson P, DeLong C. 2009. Hardwood Tree Survival in Heavy Ground Cover on Reclaimed Land in West Virginia: Mowing and Ripping Effects. Journal of Environmental Quality 38: 1400-1409. DOI: 10.2134/jeq2008.0297.

SMAGDF (Secretaría del Medio Ambiente del Gobierno del Distrito Federal). 2010. Sistema de Información de Barrancas. <http://www.sma.df.gob.mx/barrancas/> (accessed January 18, 2011).

StatSoft, Inc. 2004. STATISTICA (data analysis software system), Version 7.0. [Computer Program] $<$ http://www.statsoft.com>

Vázquez-Yanes C, Batis AI, Alcocer MI, Gual M, Sánchez C. 1999. Árboles y arbustos potencialmente valiosos para la restauración ecológica y la reforestación. Reporte técnico del proyecto J084. México D.F.: Comisión Nacional para el Conocimiento y Uso de la Biodiversidad e Instituto de Ecología, UNAM.

Vesk PA. 2006. Plant size and resprouting ability: trading tolerance and avoidance of damage? Journal of Ecology 94: 1027-1034. DOI: 10.1111/j.1365-2745.2006.01154.x.

Walters MB, Reich PB. 2000. Seed size, nitrogen supply, and growth rate affect tree seedling survival in deep shade. Ecology 81: 1887-1901. DOI: 10.2307/177279.

Westoby M, Leishman M, Lord J, Porter H, Schoen DJ. 1996. Comparative ecology of seed size and dispersal. Philosophical Transactions of the Royal Society B: Biological Sciences, 351: 1309-1318. DOI: 10.1098/rstb.1996.0114.

Whitman DW, Agrawal AA. 2009. What is phenotypic plasticity and why is it important? In: Whitman DW, Ananthakrishnan TN, eds. Phenotypic Plasticity of Insects. Science Publishers, 1-63.

Williams-Linera G, Manson RH, Isunza E. 2002. La fragmentación del Bosque Mesófilo de Montaña y patrones de uso del suelo en la región oeste de Xalapa, Veracruz, México. Madera y Bosques 8: 73-89. 
Appendix 1. Height, basal area and number of sprouts of plants of Prunus serotina, Quercus rugosa and Crataegus mexicana in 2011 and 2012, planted in 2010 in an open area and in the forest age in Barranca de Tarango, Mexico City. Values are means $\pm 1 \mathrm{SD}$.

\begin{tabular}{|c|c|c|c|c|c|}
\hline & & & 2010 & 2011 & 2012 \\
\hline \multirow[t]{6}{*}{ Height (cm) } & \multirow[t]{3}{*}{ Open area } & $P$ serotina & $35.21 \pm 2.9$ & $32.90 \pm 3.8$ & $47.0 \pm 15.6$ \\
\hline & & Q. rugosa & $26.63 \pm 3.8$ & $26.63 \pm 5.4$ & $21.0 \pm 9.5$ \\
\hline & & C. mexicana & $48.6 \pm 6.0$ & $48.5 \pm 15.2$ & $32.8 \pm 16.8$ \\
\hline & \multirow[t]{3}{*}{ Forest edge } & $P$ serotina & $33.9 \pm 3.0$ & $34.6 \pm 7.4$ & $39.0 \pm 6.3$ \\
\hline & & Q. rugosa & $28.3 \pm 4.4$ & $27.2 \pm 6.5$ & $25.8 \pm 12.4$ \\
\hline & & C. mexicana & $52.7 \pm 6.5$ & $46.2 \pm 16.4$ & $48.3 \pm 23.1$ \\
\hline \multirow[t]{6}{*}{ Basal area $\left(\mathrm{cm}^{2}\right)$} & \multirow[t]{3}{*}{ Open area } & P. serotina & $58.0 \pm 24.8$ & $50.4 \pm 26.7$ & $53.1 \pm 10.2$ \\
\hline & & Q. rugosa & $25.9 \pm 13.3$ & $29.9 \pm 16.8$ & $59.7 \pm 47.0$ \\
\hline & & C. mexicana & $65.9 \pm 21.4$ & $69.9 \pm 18.4$ & $68.3 \pm 72.8$ \\
\hline & \multirow[t]{3}{*}{ Forest edge } & $P$ serotina & $64.1 \pm 31.8$ & $60.5 \pm 31.0$ & $78.3 \pm 16.3$ \\
\hline & & Q. rugosa & $28.7 \pm 12.8$ & $34.6 \pm 16.9$ & $30.5 \pm 27.1$ \\
\hline & & C. mexicana & $64.8 \pm 23.2$ & $76.0 \pm 22.6$ & $97.3 \pm 60.6$ \\
\hline \multirow[t]{6}{*}{ Number of sprouts } & \multirow[t]{3}{*}{ Open area } & $P$ serotina & $0.07 \pm 0.25$ & $0.75 \pm 1.50$ & \\
\hline & & Q. rugosa & $0.16 \pm 0.53$ & $0.83 \pm 1.27$ & $1.14 \pm 0.69$ \\
\hline & & C. mexicana & $0.05 \pm 0.22$ & $0.33 \pm 0.49$ & $1.45 \pm 1.44$ \\
\hline & \multirow[t]{3}{*}{ Forest edge } & P. serotina & $0.07 \pm 0.25$ & $0.33 \pm 0.52$ & $0.20 \pm 0.45$ \\
\hline & & Q. rugosa & $0.22 \pm 0.75$ & $0.12 \pm 0.49$ & $1.31 \pm 1.25$ \\
\hline & & C. mexicana & $0.20 \pm 0.55$ & $1.16 \pm 2.14$ & $0.82 \pm 1.81$ \\
\hline
\end{tabular}

Appendix 2. Height, basal area and number of sprouts of plants of Prunus serotina, Quercus rugosa and Crataegus mexicana in 2011 and 2012. Plants were introduced in 2010 in Barranca de Tarango, Mexico City. Values are means \pm 1 SD.

\begin{tabular}{lccc}
\hline & $\mathbf{2 0 1 0}$ & $\mathbf{2 0 1 1}$ & $\mathbf{2 0 1 2}$ \\
\hline Height (cm) & & & \\
$\boldsymbol{P}$ serotina & $34.6 \pm 3.0$ & $33.9 \pm 6.0$ & $41.3 \pm 9.1$ \\
$\boldsymbol{Q}$. rugosa & $27.5 \pm 4.2$ & $27.0 \pm 6.0$ & $24.3 \pm 11.6$ \\
C. mexicana & $50.7 \pm 6.5$ & $47.2 \pm 15.6$ & $42.2 \pm 21.9$ \\
\hline Basal area $\left(\mathbf{c m}^{2}\right)$ & & & \\
$\boldsymbol{P}$ serotina & $61.0 \pm 28.6$ & $56.4 \pm 28.3$ & $71.1 \pm 18.6$ \\
$\boldsymbol{Q}$. rugosa & $27.3 \pm 13.1$ & $32.7 \pm 16.8$ & $39.4 \pm 35.9$ \\
C. mexicana & $65.5 \pm 22.2$ & $73.3 \pm 20.8$ & $85.9 \pm 65.9$ \\
\hline Number of sprouts & & & \\
$\boldsymbol{P}$ serotina & $0.1 \pm 0.3$ & $0.5 \pm 1.0$ & $0.1 \pm 0.4$ \\
$\boldsymbol{Q}$. rugosa & $0.2 \pm 0.6$ & $0.4 \pm 0.9$ & $1.3 \pm 1.1$ \\
C. mexicana & $0.1 \pm 0.4$ & $0.8 \pm 1.7$ & $1.1 \pm 1.7$ \\
\hline
\end{tabular}

